\title{
ВИДОВЫЕ ОЧЕРКИ
}

\section{About Records of the Blakiston"s Fish Owl on the Northern Coast of the Sea of Okhotsk, Russia \\ О ВСТРЕЧАХ РЫБНОГО ФИЛИНА НА СЕВЕРНОМ ПОБЕРЕЖЬЕ ОХОТСКОГО МОРЯ, РОССИЯ}

\author{
Utekhina I.G. (Magadan State Nature Reserve, Magadan, Russia), \\ Potapov E.R. (Bryn Athyn College, Bryn Athyn, Pennsylvania, USA) \\ Утехина И.Г. (ФГБУ «Государственный заповедник «Магаданский»), \\ Потапов Е.Р. (Брин Афинский Колледж, Пенсильвания, США)
}

\section{Контакт: \\ Ирина Г. Утехина ФГБУ «Государствен- ный заповедник "Магаданский" 685000, Россия, г. Магацан, ул. Кольцевая, А. 17 тел.: 89140397321 , 84132657871 steller@magterra.ru, irinautekhina@ gmail.com \\ Евгений Потапов eugenepotapov@ gmail.com \\ Contact: \\ Irina Utekhina \\ Magadan State Nature Reserve \\ Koltsevaya str., 17 Magadan, \\ Russia, 685000 tel.: 89140397321 , 84132657871 steller@magterra.ru, irinautekhina@ gmail.com}

Eugene Potapov eugenepotapov@ gmail.com

\section{Резюме}

Рыбный филин (Ketupa blakistoni) - редкий эндемичный восточноазиатский вил, населяюший бассейны рек Японского и Охотского морей. Ао последнего времени границу распространения рыбного филина на северном побережье Охотского моря ограничивами долинами рек Челомджа и Яна, впадаюшими в Тауйскую губу Охотского моря. В статье приводятся все известные на сегодняшний день сведения о встречах рыбного фрилина на северном побережье Охотского моря в границах Магаданской области. Постоянные наблюдения и фиксация голоса рыбного филина с начала XXI века в долине р. Яма (залив Шелихова) на территории ЯМского участка заповедника "Магаданский" позволяют продвинуть северо-восточную границу его ареала ещё на 280 км к востоку. По встречам в разные годы на р. Яма можно вылелить от 3-х $ы$ 5-ти участков обитания рыбного филина.

Киючевые слова: редкие виды, пернатые хищники, совы, рыбный филин, Кetupa blakistoni, гнездовой ареал, Магаданский заповедник.

Поступима в редакцию: 06.04.2017 г. Принята к публикации: 12.04.2017 г.

\section{Abstract}

The Blakiston's Fish Owl (Ketupa blakistoni) is a rare endemic of eastern Asia, breeding in the Sea of Japan and Sea of Okhotsk basin. Up until now, the northern limits of the breeding range was thought to be the Chelomdja and the Yana rivers of the Tauy bay of the Sea of Okhotsk species were reported from the beginning of 21 Century in the Yama portion of the Magadan State Reserve. This means that the breeding range limits is located $280 \mathrm{~km}$ further East. The Yama river is estimated to have from 3 to 5 breeding territories of the Blakiston's Fish Owl.

Keywords: rare species, raptors, owls, Blakiston's Fish Owl, Ketupa blakistoni, breeding range, Magadan State Nature Reserve.

Received: 06/04/2017. Accepted: 12/04/2017.

DOI: $10.19074 / 1814-8654-2017-34-83-88$

Северо-восточная граница ареала рыбного филина (Ketupa blakistoni Seebohm, 1884) Ао сих пор точно не установлена. Первое упоминание об обитании рыбного фрилина на северном побережье Охотского моря содержится в "Полном определителе птиц СССР» С.А. Бутурлина и Г.П. Аементьева. Оно слелано на основании сообшения Охотско-Колымского краеведческого музея (ОККМ) в г. Магадан (ныне Магаданский областной краеведческий музей) о добыче одного экземпляра рыбного филина весной 1938 г. "в районе пос. Армань около Тауйска на северном побережье Охотского моря" (Аементьев, 1941). Однако по этому высказыванию невозможно точно судить о месте находки этой птицы, так как пос. Армань расположен в устье р. Армань, а пос. Тауйск - на
Until now, the northeastern limits of the Blakiston's Fish Owl's (Ketupa blakistoni) breeding range has not been established. Dementiev (1940) was the first to mention this species to occur on the coast of the Sea of Okhotsk based on the specimen taken in spring of 1938. Vaskovskiy (1956) mentioned regular sightings of the species in the environs of Magadan. He stated that four specimens of fish owl were curated at the Magadan City museum. Unfortunately, these specimens did not survive to present time. In the annotated checklist of the birds of the North-Eastern USSR Vaskovskiy (1959) mentioned the Blakiston's Fish Owl as a "all-year-round" species in the mountains of the northern Sea of Okhotsk coasts and in the Yama-Tauy depression. Andreev (2006) mentioned this species at the Inya 


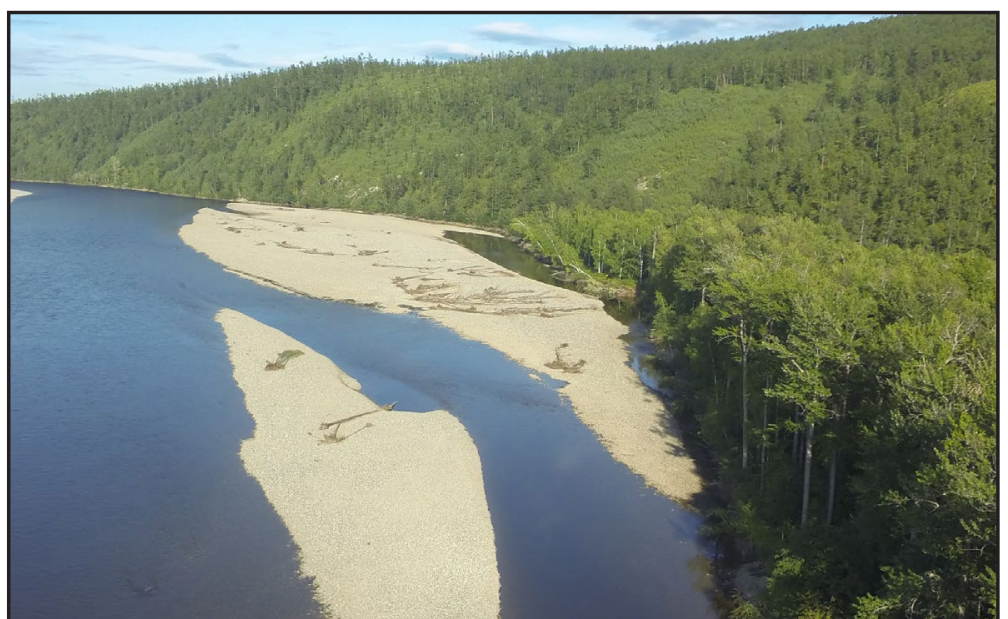

Местообитания рыбного фииина (Ketupa blakistoni) в верховьях р. Челомжи. Фото Е. Потапова.

Habitat of the Blakiston's Fish Owl (Ketupa blakistoni) at the upper reaches of the Chelomdja river. Photo by E. Potapov.

берегу Охотского моря между реками Яна и Тауй. В цитируемом определителе вид указан как Ketupa zeylonensis. Под этим же названием рыбный филин упоминается в статье А.П. Васьковского (1956) как виА, который Аовольно часто встречается в окрестностях г. Магацана. Автор сообщает о четырёх экземплярах рыбного фииина (без указания времени и места их добычи), храняшихся в ОККМ. Аишь Аля оАного из них указано, что он добыт в "47 км к северу от Магахана". К сожаиению, к настояшему времени в фондах Магацанского областного краеведческого музея ни одного из этих экземпляров не сохранилось. В опубликованном списке птиц Северо-Востока СССР А.П. Васьковский (1966) определил рыбного филина как виА "пребываюший круглый гоА" в горной части северного Охотоморья и таёжной части Ямо-Тауйской депрессии. А.В. Андреев (2006) отмечаи рыбного сримина на р. Иня. А.А. Кишинский (1968), работавший с июня по сентябрь 1963 г. на побережье зал. Шелихова в бассейнах рек Булун, Такора, Тополовка, Угулан и Наслачан и летом 1964 г. на побережье заи. Бабушкина, в обследованных районах рыбного фрилина не обнаружил. Он ограничивает границу распространения рыбного фииина на северном побережье Охотского моря к востоку до Магадана (Кишинский, 1988).

О наблюдениях зимуюших рыбных фриминов на р. Челомлжа (бассейн р. Тауй, Тауйская губа) в заповеднике "Магаданский" зимой 1983/84 и 1984/85 гг. впервые сообшили С.В. Тархов и Е.Р. Потапов (1986). В последуюшие годы рыбного филина на Кава-Челомджинском участке заповедника отмечами регулярно, инсормация об этом содержится в Летописях природы заповеАника "Магаданский" (Андреев и Ар., 2011). В июне 2003 г. на р. ЧеломАжа по голосам было учтено 10 гнездовых пар рыбно- river. Kishinskiy $(1968,1988)$ considered the northeastern limits of the Blakiston's Fish Owl breeding range to be somewhere west from Magadan city.

The Blakiston's Fish owls were first recorded wintering in the Magadan State Nature Reserve in 1983/84 and 1984/85 by Tarkhov and Potapov (1986). Later, the Blakiston's Fish Owl has been regularly reported from the Kava-Chelomdja portion of the Magadan State Nature Reserve (Andreev et al., 2011). In June 2003 ten breeding pairs were recorded on the basis on the territorial calls, and the total number of the Blakiston's Fish Owls breeding in the Chelomja River was estimated to be 10-12 pairs (Andreev, 2006).

Two nests found at the Chelomdja river were examined by professional ornithologists. One nest in May 2004 had one chick (Andreev, 2006). It was located at the top of the broken poplar tree trunk. In 2015 the owls raised one chick in the nest built by a Steller's Sea Eagle (Haliaeetus pelagicus) in the previous ear. The nest was located at a fork of the poplar tree growing at the bank of a small and quiet river stretch (Utekhina et al., 2016). The easternmost nest of the Blakiston's Fish Owl was found at the confluence of Yana and Narauly rivers by the late wildlife warden V. A. Soloviey (pers. comm) at the end of 1980 s. The nest was in the hollow of a larch tree in the old-grown forest in the river valley. In the same region (between the Narauly and Seimkan rivers, the eastern tributaries of the Yana river) the calls of the Blakiston's Fish owls were heard in 1980s, and in 1999 two fledglings were shot by poachers (Andreev, 2006).

Andreev (2006) considered the Yana river to be the northeastern border of the breeding range of the Blackiston's Fish Owl, and described the Chelomdja and Inya rivers as the strongholds of the breeding population. The only suitable habitat for the Blakiston's Fish Owl's breeding outside of the previously defined breeding range was the lower portion of the Yama river, as its physical characteristics and fish abundance were comparable that of the Chelomdja and Inya River (Andreev, 2006).

We have three reports of the Blakistons's Fish Owl in the regions east from Magadan: one from Serdjak river (1987); another from the Mayakan River (late 1980s) and the third from the Siglan river (1990s). The specimens procured in winters of 1989 and 1997 were known from North-Evensk 
Тополёвые леса ные местообитания рыбного филина. Река Челомжа, Магацанская область.

Фото Е. Потапова

Poplar tree stands along rivers are the main habitat of the Blakiston's Fish Owl. Chelomdja River, Magadan region. Photo by E. Potapov. вАоль реки - основ-

го филина, а потенциаиьную численность вила в бассейне р. Челомджа А.В. Андреев оценил в 10-12 пар (Андреев, 2006).

На р. Челомлка были найдены два, осмотренных орнитологами, гнезАа рыбного филина. Гнездо с одним птенцом, обнаруженное А.В. Андреевым в мае 2003 г. (АнАреев, 2006), располагалось на вершине об^оманного ствола тополя в срединной части зрелого пойменного леса. В 2015 г. фрилины вывели одного птенца в гнезде белоплечего орлана (Haliaeetus pelagicus), расположенном в развилке живого тополя, стояшего на берегу реки в устье маленькой тихой протоки (Утехина и др., 2016). Самое восточное гнезАо рыбного фрилина было найдено в конце 1980-х голов на р. Яна в устье её притока Нараули в середине марта охотоведом В.А. Соловьём (личное сообщение). Гнездо располагалось в дупле лиственницы в старом пойменном лесу. В этом же районе (межиу устьями левых притоков Яны Сеймкан и Нараули) в 1980-х годах голос рыбного срилина слышаи В. Правосудов (Аичное сообшение),

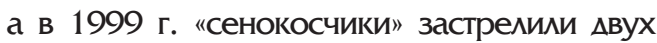
слётков рыбного филина (Андреев, 2006).

По мнению А.В. Андреева (2006), восточная граница гнездового ареала рыбного филина к концу XX века ограничиваиась Аолиной р. Яна (Тауйская губа Охотского моря), но устойчиво он обитает лишь в Аолинах рек Челомлка и Иня. Современный уровень освоения, промысловых нагрузок и антропогенного беспокойства в Аолинах рек Тауйской губы искиючает возможность возникновения даке временных гнездовых группировок рыбного ффилина. ЕАинственной, подходяшей мия устойчивого существования рыбного филина, рекой к востоку от Магадана является долина р. Яма в её нижнем течении. Характер местообитаний и обилие рыбы в этой реке сравнимы с $\Delta$ линами ЧеломАки и Ини (Андреев, 2006).

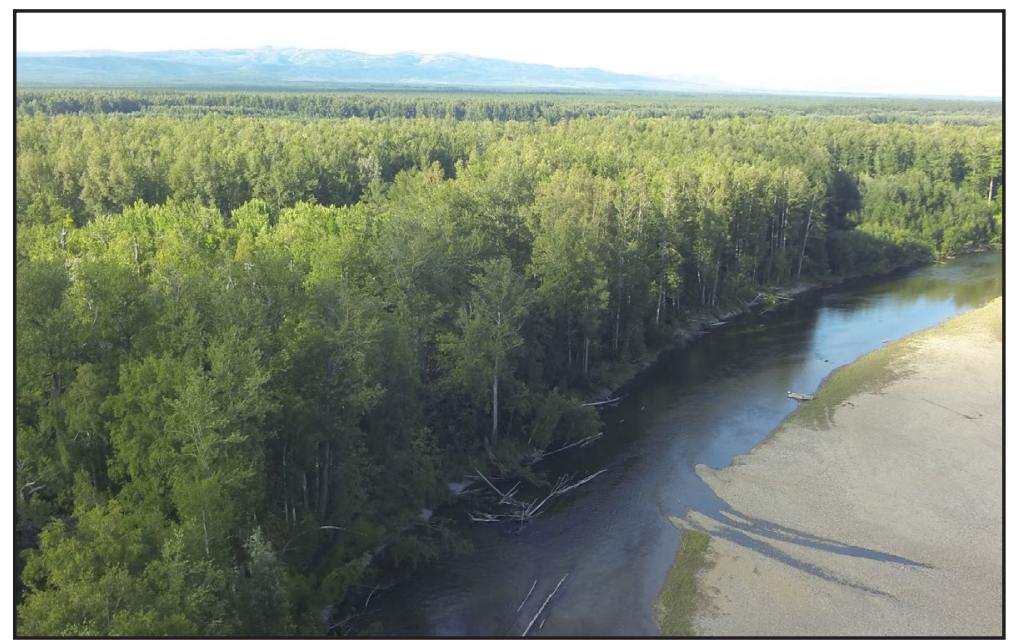

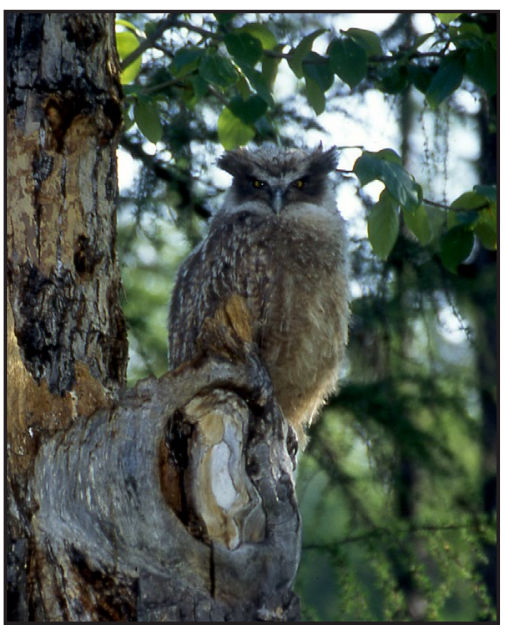

Слёток рыбного филина, р. Челомцжа, 2003 г. Фото А. Андреева

Fledgling of the Blakiston's Fish Owl, Chelomdja river, 2003. Photo by A. Andreev.

Region of the Magadan District, but unfortunately, no vouchers were examined by specialists. The Blakistons' Fish Owl's calls were first recorded by us in the Yama River on August, 12, 1997 in the Magadan State Nature Reserve downstream from the Yama and Flochoschan river confluence ( $N$ 59.82275, E 153.36575). The Yama river flows to the Yama bay, Gulf of Shelikhova, Sea of Okhotsk.

Later, the Magadan State Nature Reserve rangers have been reporting the Blakiston's Fish Owl's sightings and calls. Three reports were from the Yama and Studenaya river confluence in the fall of 2005 and one sighting was downstream from the Studenaya ranger's station in August 2008. In 2006 one owl flew to the ranger's station Khalanchiga, at the border of the Magadan Nature Reserve, and during 2011-2016 the sightings and display calls became regular. In 2012, while building a new ranger's station called Neuter, the rangers reported frequent display calls (fig. 1). On May 21, 2013 ranger T. Glushnev reported the Blakiston's Fish Owl flying near the Neuter ranger's station, and its calls at the Neuter on 10 May and 17 June, as well as at the Studenaya ranger's Station on June 2, 8, 10, 18 and 22, 2013. After the Neuter ranger's station building was complete, the owl moved to the western bank of the Yama river, across the ranger's station, where there were large poplar trees with hollows and broken trunks. The calls of the owls were also reported from the Neuter ranger's station in April - May, 2015. In 
Мы располагаем несколькими устными сообшениями о встречах рыбного фииина на восток по побережью от Магадана. Охотове А В.А. Соловей (личное сообшение, 1990-е годы) слышаи и наблюдаи птиц в весенний период на р. Сиглан (заи. Забияка, восточнее Тауйской губы). В 1987 г. охотники застрелили филина на р. Сердяк (приток р. Ола, Тауйская губа), определённого В.А. Соловьём как рыбный. Таксидермист Е.С. Коренева сообшила, что в конце 1980-х годов она делала чучела 2-х рыбных фииинов, привезённых охотниками с р. Маякан (приток р. Яма, Ямская губа, заи. Шелихова). О зимних находках рыбного фрилина в Северо-Эвенском районе Магаданской области сообшил охотовед этого района С.А. Матвиенко: в 1989 г. одна птица попаиась в капкан на р. Наяхан в устье её притока р. Тэнкэли; 1 марта 1997 г. рыбный срилин был пойман охотниками в загородку на лису на р. Крутая около р. Наяхан. К сожаиению, до специаиистов эти птицы не Аошли.

Указание А.В. Андреева (2006) на встречу рыбного срилина на р. Яма в районе её притока р. Тоб, основанное на нашем устном сообшении, ошибочно. Мы впервые услышами рыбного фиилина на р. Яма 12 августа 1997 г. во время проведения мониторинга гнездования белоплечего орлана в заповеднике "Магаданский" ниже правого притока Флохосчан (N 59,82275, Е 153,36575).

Сообшения о встречах филина на Ямском участке заповедника "Магаданский" от инспекторов заповедника стами поступать в 2000-х годах. Инспектор В. Остапченя слышал вечерние крики фрилина 13 сентября и 12, 14 октября 2005 г. в левобережье Ямы напротив устья р. Студеная. В 2008 г. этот же инспектор слышал крики фрилина ниже по течению Ямы от кордона Студеная ночью 23 августа.

Филин прилетаи на территорию кордона Хачанчига, расположенного у нижней границы Ямского участка заповедника, 29 сентября 2006 г. Крики рыбного срихина «с ве-

Рис. 1. Рыбный филин (Ketupa blakistoni) в пойме p. Яма, выше заповедника "Магацанский". 20.02.2013 г. Фото И. Учуева.

Fig. 1. Blakiston's Fish Owl (Ketupa blakistoni) in the floodplain of the Yama river near the Magadan State Nature Reserve. 20/02/2013. Photos by I. Uchuev.
2015 birds were sighted and calls were reported from July 19 to August 16 by the ranger V. Ostapchenya. In 2016 ranger V. Loskutov heard the display calls at the Neuter from October to December. At the end of February 2017 a call of the Blakiston's Fish Owl was reported by S. Shvetsov. During night of March, 4 a duet call was reported some $50 \mathrm{~m}$ away from the station (Uchuev, pers. comm).

It appears that the sightings of the Blakiston's Fish Owl at the Yama River were not of vagrants. The observations suggest that in different years the Yama river accommodates from 3 to 5 territories of the Blackiston's Fish Owls located at Khalanchiga (1), Studenaya (2), Flochoschan (3), Neuter (4) and some $15 \mathrm{~km}$ upstream from the northern border of the Magadan State Nature Reserve (5) (fig. 2). The distances between the territories were from 8 to $18 \mathrm{~km}$ along the river valley, which is close to the inter-pair distances of the Chelomdja river as revealed by the counts of 2003: 1 pair for $8-10 \mathrm{~km}$ of the river length (Andreev, 2006).

Despite the lack of nest findings on the Yama River, it appears that the breeding range of the Blakiston's Fish owl has spread since 1980s some $280 \mathrm{~km}$ northeast, and reached the Yama river (fig. 3) by the end of 1990 s.

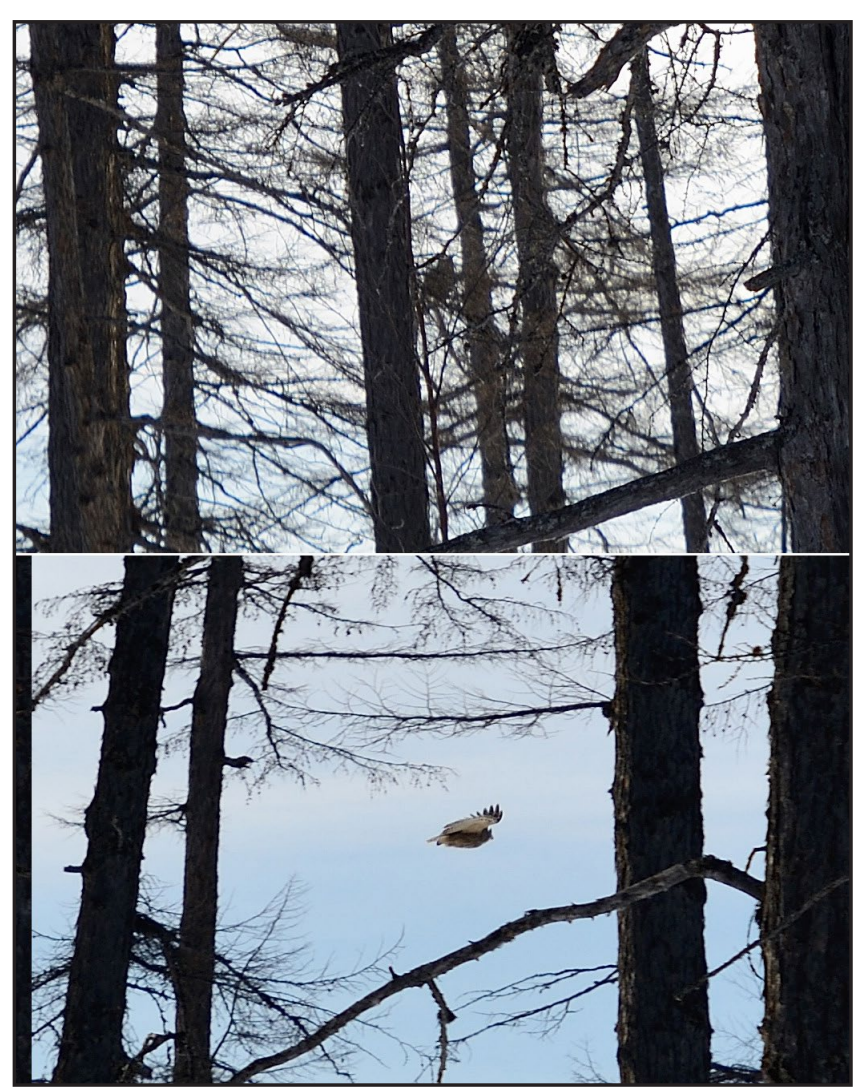




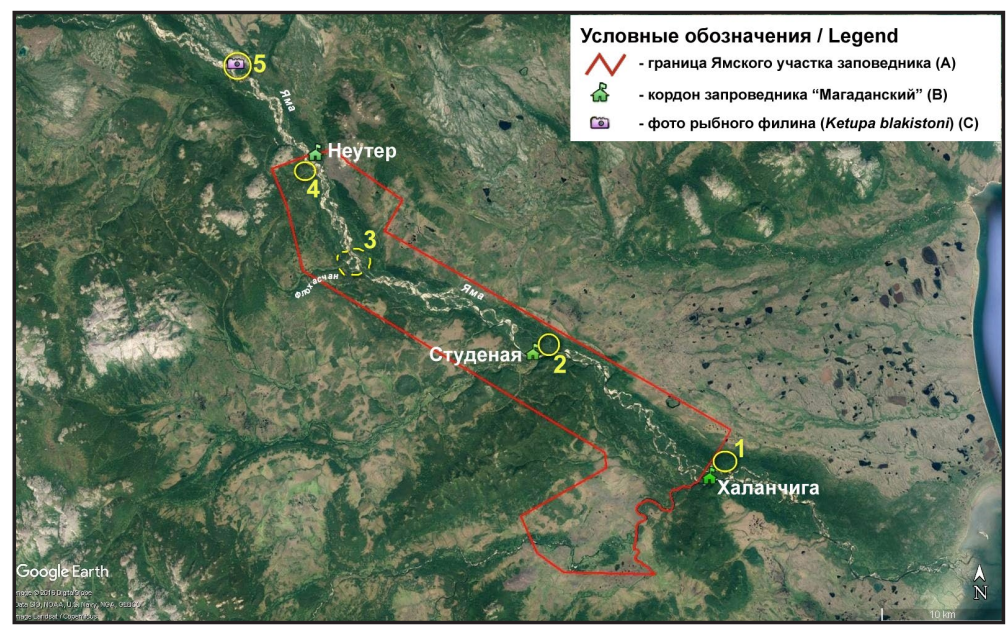

чера Ао глубокой ночи" слышами 30 сентября и 2 октября 2006 г. инспектора на кордоне Халанчига. В 2011 г. инспектор С.А. Мондо отметил в Аневнике наблюдений от 2 марта, что кажыый вечер напротив кордона Хаманчига ухает филин. Вторая и последняя запись об уханье фииина позАно вечером на противоположной от кордона стороне реки слелана им 11 марта. В 2012 г. от инспекторов с кордона Хаманчига есть единственное сообшение от 15 сентября о том, что "в районе протоки Пронино по вечерам кричит силин". В 2016 г. уханье филинов в левобережье р. Яма напротив кордона Хаманчига в вечерние часы (21:00, 22:00) ежедневно с 3 по 7 июня отмечаи инспектор С.А. Мондо.

С начала строительства в 2012 г. кордона Неутер у верхней границы Ямского участка, инспектора заповедника стами регумярно отмечать крики срилина и его встречи вблизи нового кордона. Сушествует видеозапись рыбного филина, слеланная инспектором В.А. Остапченей в сентябре 2012 г. возле кордона Неутер в 30 м от жилья (филинов было Ава, но заснять удаАось только одного). Он же, передвигаясь на снегоходе, 17 февраля 2013 г. спугнул 2-х фрилинов, силящих на деревьях на ле-
Рис. 2. Места встреч рыбного филина в Аолине р. Яма.

Fig. 2. Records of the Blakiston's Fish-Owl in the Yama river valley.

вом берегу Ямы в 15 км выше заповедника. Инспектор И.В. Учуев ссотографировал рыбного филина 20 февраля 2013 г. в 10 км выше кордона Неутер за территорией заповедника на левом берегу р. Яма филин силел на дереве в коренном лесу у берега незамерзаюшей проточки (рис. 1).

К сожалению, в последние годы наблюдения от инспекторов Ямского участка поступают в архив заповедника нерегулярно, но в сАанных Аневниках наблюдений записи о рыбном филине присутствуют постоянно.

В 2013 г., инспектор Т.С. Глушнев 21 мая видел срилина, пролетаюшего мимо кордона Неутер, а уханье слышаи на кордоне Неутер (10 мая и 17 июня) и на кордоне Студеная (2, 8, 10, 18 и 22 июля). В 2014 г. инспектор В. Остапченя отметил, что после строительства кордона Неутер фииин перебраися на правый берег Ямы напротив кордона. Там расположен участок леса с огромными тополями с дуплами и обломанными верхушками. Крики филина по ночам на кордоне Неутер отмечаии в апреле - мае. Инспектор И.В. Учуев во второй половине апреля на правом берегу р. Яма в старом тополёвнике (участок метров 100 в ширину и метров 200 в миину на границе с лиственничником) видел саму птицу. В 2015 г. с 19 июля по 16 августа самих птиц и их крики около кордона Неутер отмечаи регулярно в вечерние и ночные часы инспектор В. Остапченя. В 2016 г. инспектор В.Н. Аоскутов за период с октября по декабрь слышаи и наблюдаи рыбных филинов возле кордона Неутер: голос одного рыбного фрилина 14 октября (с 19:20 Ао 20:45), кричашую дуэтом пару 1 ноября (с 19 Ао 19:45), пару (“силели на самой вершине чозении возле Аомика и ухами") 12 ноября вечером, одного возле кордона 19 ноября (с 20:40 $\Delta$ о 21:10), 20 ноября (с 19:00 $\Delta$ о 20:45) и 30 ноября утром (с 7:00 $\Delta$ о 7:45). В 2017 г. первый раз крик одиночного филина инспектор С.Н. Швецов отметил в конце февраия на правом берегу Ямы в пойменном ^есу напротив кордона Неутер. После этого поздно вечером 4 марта пару сииинов, кричаших Ауэтом, видели и сыышаии в 50 м от кордона (И.В. Учуев, личное сообшение).

Судя по этим наблюдениям все встречи рыбного филина на р. Яма не являются случайными. По встречам в разные 
Рис. 3. Распространение рыбного фияина на северном побережье Охотского моря.

Fig. 3. Distribution of the Blakiston's Fish Owl on the northern coast of the Sea of Okhotsk.

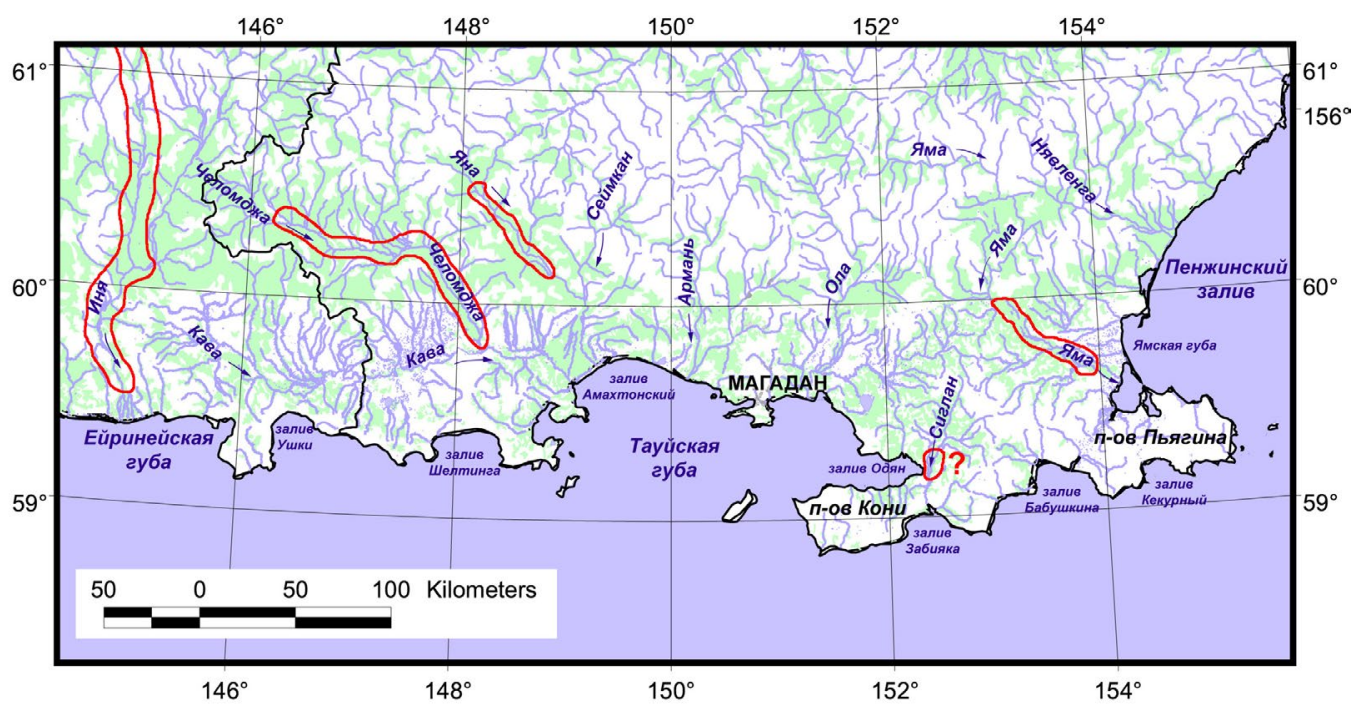

годы на р. Яма можно выделить от 3-х до 5-ти участков обитания рыбного фииина - в районе устьев Хаианчиги (1), Студеной (2), Флохосчана (3), Неутера (4) и в 15 км выше верхней границы заповедника "Магаданский" (5) (рис. 2). Расстояние между точками, где отмечали срилина, составляют от 8 Ао 18 км Аолины Ямы, что примерно соответствует плотности распределения вида на р. ЧеломАжа - 1 пара на 8-10 км долины, полученной во время учёта 2003 г. (Андреев, 2006).

Несмотря на отсутствие находок гнёзд на р. Яма следует, по-видимому, признать, что в первом десятилетии XXI века граница гнездового ареала рыбного срилина продвинулась на 280 км Ааиьше на восток, по крайней мере, $\Delta о$ долины р. Яма (Ямская губа заи. Шелихова, Охотское море) (рис. 3).

\section{Митература}

Анцреев А.В. Рыбный филин (Ketupa blakistoni) на Северо-Восточной окраине ареала. - Геология, геограсрия и биологическое разнообразие Северо-Востока России: Материаиь $\triangle$ аиьневосточной регионаиьной конференции, посвященной памяти А.П.Васьковского и в честь его 95-летия (Магацан, 28-30 ноября 2006 г.). Магацан: СВНЦ $\triangle \mathrm{BO}$ РАН, 2006. С. 309-312 [Andreev A.V. Blakiston's Fish Owl (Ketupa blakistoni) in the North-Eastern corner of its range. In: Geology, Geography and Biodiversity of the Russian North East: Proceedings of the Far-Eastern regional conference in the Memory of and commemoration of $95^{\text {th }}$ birthday of A.P. Vaskovsiy, Magadan, 28-30 Novebmer 2006. Magadan, North Eastern Center of the Far Eastern Branch of the Russian Academy of Sciences, 2006: 309-312].

Андреев А.В., Кречмар А.В., Утехина И.Г. Птицы. - Растительный и животный мир заповедника "Магаданский". Магадан: СВНЦ $\triangle \mathrm{BO}$ PAH, 2011. C. 129-155. [Andreev A.V., Krechmar A.V., Utekhina I.G. Birds. - The plant and animal life of the State Nature Reserve "Magadansky". Magadan, 2011: 129-155].

Васьковский А.П. Новые орнитологические находки на северном побережье Охотского моря. - Зоологический журнал. 1956. Т. XXXV. Вып. 7. С. 1051-1058. [Vaskovskiy A.P. New ornithological records on the northern coast of the Sea of Okhotsk. - Zoological journal. 1956. 35(7): 1051-1058].

Васьковский А.П. Список и геограсическое распространение птиц Крайнего Северо-Востока СССР. - Краеведческие записки. Магадан, 1966. Вып. 6. С. 84-124. [Vaskovskiy A.P. List of birds of the Far North-East USSR and their geographical distribution. - Local history notes. Magadan, 1966. 6: 84-124].

Аементьев Г.П. Аополнение к томам первому, второму, третьему и четвертому «Полного определителя птиц СССР». - Полный опредемитель птиц СССР. Т. 5. М.; А.: КОИЗ, 1941. C. 13-94. [Dementiev G.P. Addition to the volumes of the first, second, third and fourth "Full Guide of Birds of the USSR". - Full Guide of Birds of the USSR. Vol. 5. Moscow, Leningrad, 1941: 13-94].

Кишинский А.А. Птицы Колымского нагорья. М.: Наука, 1968. 188 с. [Kishchinsky A.A. Birds of the Kolyma Highland. Moscow, 1968: 1-188].

Кишинский А.А. Орнитофрауна северо-востока Азии: История и современное состояние. M.: Наука, 1988. 288 c. [Kishchinsky A.A. Ornithofauna of the Northeast Asia: History and current status. Moscow, 1988: 1-288].

Тархов С.В., Потапов Е.Р. Зимовка рыбного срилина в Магаданской области. - Актуальные проблемы орнитологии. М.: Наука, 1986. С. 239-240. [Tarkhov S.V., Potapov E.R. Wintering of the Blakiston's Fish Owl in the Magadan District. Actual Problems of Ornithology, Moscow, Nauka Publishers, 1986: 239-240].

Утехина И.Г., Потапов Е.Р., МакГрахи М.Аж. Гнездование рыбного фииина в гнезде белоплечего орлана, Магаданская область, Россия. - Пернатые хишники и их охрана. 2016. № 32. C. $126-129$. DOI: $10.19074 / 1814-8654-2016-32-$ 126-129 [Utekhina I.G., Potapov E.R., McGrady M.J. Nesting of the Blakiston's Fish-Owl in the Nest of the Steller's Sea Eagle, Magadan Region, Russia. - Raptors Conservation. 2016. 32: 126-129. DOI: $\quad 10.19074 / 1814-8654-2016-32-126-129]$. URL: http://rrrcn.ru/ru/archives/26957 Аата обрашения: 01.04.2017. 